\title{
President's message: NACA annual meeting 2007
}

\author{
"It was the best of times, it was the worst of times; it was the season of Light, it was the season of \\ Darkness..."
}

\section{It was sometime around 1760 when the city of Birmingham exhaled - spewing into the air a great cloud of grey. The world took a deep breath and was at once intoxicated. The Industrial Revolution had begun.}

That, ladies and gentlemen, is the reason we're here.

NACA is looking ahead and in doing that we also need to look to the past. It's important that we remember what it is that we do and the reason we do it. Ultimately the gift of clean air is something we want to give to our children. I say that as the President of Naca and a father the two.

To make a difference, we need to be a collective force - standing shoulder to shoulder. We need to influence legislation, promote awareness and educate. We need to be the gatekeeper of good science and provide a platform for discussion. Ours must be a voice that is sound, forceful and constant. These are the arms of NACA.

Our vision is clear. We want to create an easily accessible platform for all air-related issues, where anyone, anywhere and at anytime can contribute, get information and grow. In other words, we want to become the first port of call.

I am happy to report that it's not a lot of hot air. Our vision is being realised. And, the Naca News which I'll talk about later is a tangible expression of that.

In case anyone doesn't know facts around the news of my appointment, I would just like to talk a little about that. Essentially Greg Scott went to government and Yvonne Scorgie went to Australia - where she tells me her biggest job so far - has been to sort out the stink from chicken farms.

I would just like to thank, Yvonne and Greg for their many years of dedication. Theirs are very big shoes to fill. But, with the great support of Thandi Radebe and council, I think we're doing okay.

And now I am going to tell you want we've done.

\section{PEAT}

For starters... In terms of the National Framework, Naca successfully conducted workshops with our members throughout the country - and that given the short 30-day deadline. Our comments are now with the Department.

And, on the subject of Government...

As most of you know, the Department of Environmental Affairs held its stakeholder workshop on Air Emission Standards yesterday. Most of you know because you were there - I hope.
The fact that the DEAT conference takes place in the same week as ours is no co-incidence. It is the result of an agreement signed in July this year. Essentially, we've agreed that for the next four year's we'll co-ordinate our conferences. And that's not just because we might get group discounts on accommodation - although we hope that's true. The real reason is that it means we'll have all the right people at the right place at the same time.

\section{Communication}

We have also raised the bar in communication. Our newsletter has a dynamic new look and for the first time we are including content from outside of NACA.

Our first edition boasts contributions from awardwinning science journalists like Leonie Joubert; and super-athlete, Bruce Fordyce - he has a thing or two to say about air.

And, even the Executive Producer of Carte Blanche, has made some time for our news.

It makes for interesting reading that has appeal beyond the Air Quality industry. So from now on, it's not the NACA Newsletter, it's the Naca News. We hope that our new approach will make Air Quality and the science behind it accessible to all.

Naca has also made in-roads into television with high-profile interviews on SABC's Rights and Recourse as well as Mnet's Carte Blanche.

Internally, we are also moving forward. Our branches have held several seminars around the country. We've discussed, grappled and debated. Sometimes we've even argued - all in the name of Air Quality. We're hoping to do that for the first time in the North West Province this year.

\section{Finances}

We are in a strong financial position. Even though we are spending money in new areas, we've managed to find sponsorship for those projects. So, we're still flush. The financial report has been signed off and submitted.

\section{$\underline{\text { Awards }}$}

A little later this evening, we'll be toasting some of South Africa's best Air Quality ambassadors. Our awards recognise those men and women who've made outstanding contributions to the field. Some 
have spent a lifetime improving the air we breathe, others are breaking new ground in Air Quality management and we salute them.

\section{Team}

I'd also like to salute the members of NACA - I addition to their normal work loads, they volunteer their time and expertise in the pursuit of excellence. They are some of the best people I know - all with a common goal - and that is better air.

First among them was Piet Odendaal who sadly past away last month. His passing came as a blow to me and many others. I was with Piet in Brisbane just days before and was impressed with the depth of the friendships he'd formed with his colleagues from around the world. He really held Naca together and helped keep us on course. He is sorely missed.

On a happier note, we'd like to welcome Templeton Titima who is the new Chairperson for the Eastern Cape. We're excited to have you on board.

Welcome also to our new administrator Sandy Kent. As a full-time member of the team, she's making it possible for us to get a whole lot more done.

I'm sure everyone agrees that the Kwa-Zulu Natal branch has done a great job organising this year's conference. There really is a tremendous amount of work and energy that goes into making this happen. So thank you.

And finally I've kept the best news till last - I'm very happy to announce that Piet Odendaal and I did some real work in Australia which was home to this year's International Union of Air Pollution Prevention Associations conference,

We went there with a mission and that was to bring IUAPPA home. We did it! And it gives great pleasure to tell you that next year, we'll be hosting IUAPPA's regional conference on South African soil. It will coincide with our annual Naca conference.

But we're not stopping there - we have our sights set on 2013. And, will be putting in our bid to host the $16^{\text {th }}$ IUAPPA world conference.

So, with more than enough work to keep us busy for another year, I'd like to hand over to the Chairpersons of the Branches for their reports, and leave you with a quote from George Burns who was 97 when he said: "I remember a time when sex was dirty and air was clean'. I hope that when I'm ninety-odd, I'll be able to say, at least, that the air is clean.

Thank you. 